\title{
KEWENANGAN PERADILAN AGAMA DALAM MEMUTUS PERKARA PERCERAIAN AKIBAT MURTAD
}

\author{
Fatmawati \\ Pengadilan Agama Kabupaten Bangkalan \\ Jl. Soekarno Hatta No. 19 Bangkalan \\ e-mail: fatmawati.kasmarang@gmail.com
}

\begin{abstract}
The provisions of Article 49 of Indonesia regulations No. 3 of 2006 on the Religious Court affirmed that the authority of religious courts is limited to those cases that occur among Muslims in Indonesia regarding marriage, divorce, sadaqah, infaq, testament, hibah, zakat, waqf and Islamic economic, Such arrangements may implicated the provisions litigant in court religion is Muslim (principle of personalization). In fact, the practice is common in religious courts decide divorce activity is due to apostasy. Of course it is contrary to the principle of personalization inherent in religious courts. This study is important to ensure that the actions carried out the religious courts in accordance with applicable laws and regulations in order to ensure legal certainty litigant parties in matters of divorce due to apostasy.
\end{abstract}

Keywords: competence, divorce, apostasy and religious courts.

\begin{abstract}
Abstrak: Pasal 49 Undang-Undang Nomor 3 Tahun 2006 Tentang Peradilan Agama menegaskan bahwa kewenangan peradilan agama terbatas pada perkara-perkara yang terjadi antara umat Islam di Indonesia seputar perkawinan, Perceraian, shadaqah, infaq, wasiat, hibah, zakat, wakaf, dan ekonomi syariah. Pengaturan tersebut berimpilikasi pada ketentuan yang boleh berperkara di pengadilan agama hanyalah orang Islam (asas personalisasi). Pada kenyataannya, praktik yang sering ditemui di peradilan agama ialah kegiatan memutus perceraian akibat murtad. Tentu hal tersebut bertentangan dengan asas personalisasi yang melekat pada peradilan agama. Kajian ini penting untuk memastikan bahwa tindakan yang dilakukan peradilan agama tersebut telah sesuai dengan ketentuan hukum yang berlaku demi menjamin kepastian hukum pihak-pihak yang berperkara dalam persoalan perceraian akibat murtad.
\end{abstract}

Kata kunci: kewenangan, perceraian, murtad, dan peradilan agama.

Penting dipahami bahwa baik suami ataupun istri sama-sama memiliki kewajiban untuk selalu memelihara hubungan perkawinan dengan baik. Pergaulan suami istri merupakan pergaulan yang yang paling rapat dan erat. Waktu untuk ketemu tidak dibatasi dengan waktu dan jam. Siang dan malam keduanya berkumpul dan bergaul di dalam rumah atau di luar rumah. Mereka hidup serumah, sesumur, sedapur, sebilik, dan sepebaringan. Tentu saja pergaulan yang seerat dan serapat itu membutuhkan kasih sayang, persesuaian pendapat, serasa dan sekemauan, dan berlapang dada atas berbagai persoalan yang timbul dalam perjalanan kehidupan rumah tangganya (Subekti, 2010).

Namun demikian, perjalanan kehidupan rumah tangga yang berjalan dinamis tidak menutup kemungkinan hadirnya percekcokan antar pasangan perkawianan tersebut. Dalam kondisi ini, sekalipun negara telah menganut prinsip dalam mempersulit kegiatan perceraian, namun ketentuan yang sulit itu tidak menyulutkan niat para pihak dalam mengakhiri hubungan perkawinannya. Bisa dipastikan, dalam kehidupan rumah tangga mereka telah terjadi pertentangan yang cukup prinsipil yang memandang bahwa satu-satunya usaha dalam menyelesaikan berbagai pertentangan tersebut ialah melalui mekanisme perceraian dengan konsekwensi hubungan perkawinannya berakhir (Marpaung, 1983:1).

Terdapat banyak hal yang menyebabkan lahirnya keputusan untuk melakukan perceraian antar masing-masing pasangan yang terjalin dalam 
ikatan perkawinan. Mulai dari urusan distribusi nafkah yang tidak memenuhi kriteria dalam kehidupan rumah tangga, hubungan keluarga, perselingkuhan, tuntutan kerja, hingga pada persoalan yang menyangkut keyakinan terhadap agama berupa murtad. Dalam banyak kasus, perceraian murtad ternyata memiliki peranan penting dalam menciptakan hubungan antar suamiistri berakhir dalam dengan status perceraian (Syaifuddin, Turatmiyah, Yahanan, 2013:361).

Perceraian yang diakibatkan oleh salah-satu pihak yang murtad dalam hubungan suami-istri ternyata menghadirkan persoalan tersendiri berkaitan dengan status peradilan agama dalam memutus perkara perceraian tersebut. Mengingat kewenangan absolut peradilan agama hanya dikhususkan pada persoalan-persoalan yang timbul di antara umat Islam terkait permasalahan perkawinan, perceraian, shadaqah, infaq, warsi, wasiat, hibah, zakat, wakaf, ekonomi syariah, dan persoalan lainnya, sebagaimana ketentuan Pasal 49 Undang-Undang Nomor 3 Tahun 2006 Tentang Peradilan Agama (UU Peradilan Agama).

Dengan demikian dapat disimpulkan bahwa Peradilan Agama merupakan lembaga peradilan yang menyelesaikan berbagai persoalan kekeluargaan yang terjadi di antara umat Islam. Ketentuan ini semakin diperkokoh oleh asas personalitas keislaman yang menghendaki keberadaan peradilan agama merupakan peradilan khusus bagi umat Islam. Dengan demikian, wewenang absolut Peradilan Agama tidak menjangkau persoalan kekeluargaan yang terjadi antara orang yang tidak beragama Islam Erfaniah (Zuhriah, 2014:132-133).

Sementara itu, sekalipun pendapat atau keterangan dari beberapa ahli agama/ulama memiliki pandangan yang berbeda terkait definisi murtad. Namun beberapa ulama tersebut bersepakat bahwa secara umum murtad diartikan sebagai pernyataan sikap atas keluarnya seseorang dari Islam. Murtad sendiri mengakibatkan status keislaman seseorang menjadi gugur karena telah menyatakan diri sebagai bukan penganut Islam (Moqshit, 2013:290293). Dengan artian bahwa segala hak dan kewajibannya sebagai muslim telah berakhir sejak menyatakan diri untuk tidak lagi meyakini Islam sebagai agama.

Permasalahannya ialah bahwa perceraian yang terjadi akibat murtadnya salah-satu pihak menyebabkan terjadi pergantian hubungan antara orang Islam dengan orang Non Islam akibat kemurtatannya. Dengan demikian timbul permasalahan terkait wewenang peradilan dalam memutus perkara perceraian tersebut karena salah-satu pihak bukanlah orang Islam. Fenomena tersebut sebagaimana terjadi pada Putusan Peradilan Agama Pekanbaru yang memberikan Putusan perceraian antara pihak yang disebabkan oleh murtadnya salah-satu dari pasangan tersebut. Putusan itu tercantum dalam Putusan Nomor 354/ Pdt.G/2013/PA.PBR. Dalam putusan ini, Majelis Hakim Peradilan Agama Pekanbaru memberikan putusan cerai terhadap pasangan yang mengajukan perkara ini dengan pertimbangan salah-seorang dari pasangan tersebut murtad (Putusan Peradilan Agama Pekanbaru 354/Pdt.G/ 2013/PA.PBR).

Putusan lainnya tentang perceraian yang diakibatkan oleh salah-satu pasangan murtad ialah seperti putusan Peradilan Agama Jakarta Pusat Nomor: 1000/Pdt.G/2010/PAJP serta putusan Peradilan Agama Purwokerto Nomor: 1566/Pdt.G/ 2012/PA.Pw. Majelis hakim yang mengadili dan memutus dalam perkara tersebut memberikan putusan cerai terhadap pasangan yang salahsatunya telah menyatakan diri keluar dari Islam.

Jika suatu lembaga peradilan menggelar suatu perkara sementara hal tersebut bukanlah wewenangnya, akan menimbulkan kekacauan sistem peradilan di Indonesia yang mengarah pada ketidak-pastian atas produk hukum yang telah diputusnya. Karenanya, kajian mengenai kewenangan Peradilan Agama dalam kasus perceraian akibat murtad merupakan persoalan hukum yang patut dikaji secara akademis, guna menghindari persoalan hukum berkelanjutan yang berkenaan dengan permasalahan ini.

\section{METODE}

Kajian ini merupakan kajian hukum normatif, yaitu kajian yang didasarkan pada analisis terhadap bahan-bahan kepustakaan sebagai sumber data, beberapa asas hukum serta peraturan perundangundangan yang sesuai dengan permasalahan dalam penelitian ini (Amiruddin, 2004: 166). Pendekatan yang digunakan ialah pendekatan perundangundangan (statute approach), dan pendekatan kasus (case approach), dengan sumber hukum berupa Undang-Undang Nomor 3 Tahun 2006 tentang Perubahan atas Undang-Undang Nomor 7 Tahun 1989 tentang Peradilan Agama, Undang- 
Undang Nomor 7 Tahun 1989 tentang Peradilan Agama, Undang-Undang Nomor 1 Tahun 1974 tentang Perkawinan, Kompilasi Hukum Islam (sumber hukum primer). Selain sumber hukum di atas, digunakan juga beberapa buku, jurnal, dan laporan penelitian yang berkaitan dengan tema penulisan (sumber hukum sekunder), serta kamus hukum, dan KBBI (sumber hukum tersier). Keseluruhan sumber hukum tersebut kemudian dianalisis melalui teknik analisis yuridis-kualitatif.

\section{HASIL DAN PEMBAHASAN}

\section{Murtad Sebagai Salah Satu Alasan Putusnya Perkawinan}

Menjadi Muslim dan beragama Islam merupakan hak setiap orang tanpa ada paksaan sebagaimana termaktub dalam surat Al-Kafirun ayat (6) serta surat Al-Ghasiah ayat (21-22). Bahkan jika dilakukan pengkajian lebih mendalam, sebenarnya Islam tidak melarang umatnya melakukan hubungan baik dengan non muslim yang tidak memusuhi apalagi memerangi Muslim. Hubungan kemanusiaan tersebut mencakup segala bidang kehidupan seperti tolong-menolong dalam kebaikan, penghidupan, pendidikan, ekonomi, dan lain sebagaimana ditegaskan dalam Surat AlMumtah'anah ayat (8) (Nafis, 2015: 32).

Dalam kondisi ini, perlu dikemukakan bahwa konsep universal Islam adalah memberi kedamaian bagi semua makhluk, menebarkan cinta bagi sesama manusia, dan mengkampanyekan prilaku mengasihi demi keberlangsungan kehidupan umat manusia seluruhnya sebagaimana diulas secara lugas dalam ketentuan Surat Al-Anbiya' ayat (107). Ketentuan ayat ini menegaskan bahwa hubungan Islam dengan non-Islam bukanlah suatu hubungan yang kontradiktif dengan anjuran sikap menebar permusuhan, kekerasan, dan peperangan. Akan tetapi hubungan Islam dengan non-Islam, bahkan terhadap seluruh makhluk semesta, merupakan hubungan yang terjalin mesra, romantis, damai, dan mementingkan kesejahteraan bersama antar umat manusia (Basuki, 2013).

Bertolak dari uraian di atas, secara umum murtad berarti suatu perbuatan dimana salah seorang dari suami atau istri keluar dari agama Islam. Dalam Kompilasi Hukum Islam tidak dijelaskan tentang pengertian murtad, namun hanya dijelaskan dalam Pasal 116 huruf (h) bahwa peralihan agama atau murtad yang menyebabkan terjadinya ketidakrukunan dalam rumah tangga" dimasukkan sebagai alasan perceraian. Dalam bahasa Arab murtad berarti riddah yaitu kembali ke jalan asal, sedangkan menurut syara' adalah keluar dari Islam.

Ketentuan Pasal 116 huruf (h) Kompilasi Hukum Islam di atas memiliki landasan filsafat yang kuat jika dilihat dari pandangan hukum Islam (syari'ah) dalam memberikan sanksi terhadap pelaku murtad ini. Dalam pandangan Islam, seorang pelaku murtad akan memutuskan status hukum perkawinannya. Ketentuan yang demikian didasarkan pada mayoritas pendapat imam Madzhab yang menganggap bahwa murtadnya salah-satu pasangan akan berakibat pada putusnya ikatan pernikahan yang telah mereka lalui sebelumnya. Bahkan secara tegas keempat Imam Madzhab tersebut menyatakan bahwa hubungan intim yang dilakukan pasca murtadnya salah-satu pasangan merupakan hubungan luar nikah yang bisa dikategorikan sebagai perbuatan zina (Hasan, 2003:136-137).

Murtadnya salah-satu pasangan dalam ikatan perkawinan menurut pandangan Imam Madzhab (Hanafi, Maliki, Syafi'i, dan hambali), memberikan hukum bahwa dengan murtadnya salah-satu pasangan tersebut, status pernikahan yang telah dilangsungkan telah rusak, atau dengan kata lain telah batal demi hukum. Namun demikian, terkait dengan proses perceraiannya, keempat Imam Madzhab di atas memberikan beberapa pendapat yang dimungkinkan berbeda antara satu dengan yang lainnya.

Menurut pandangan Madzhab Hanafi, perbuatan murtad yang dilakukan oleh salah seorang suami-istri itu mengakibatkan dampak yang serius terhadap status perkawinan, yaitu: Bila yang murtad adalah pihak istri, Mazhab Hanafi sepakat, perkawinan itu putus tanpa talak, alias fasakh. Karena dalam pandangan madzhab ini, istri yang telah keluar dari agama Islam merupakan penyebab putusnya suatu ikatan perkawinan secara seketika sejak dilakukannya perbuatan murtad itu. Putusnya perkawinan di sini merupakan ba'in, dengan ketentuan hukum bahwa suami tidak bisa merujuk istrinya, meskipun istrinya sudah kembali masuk Islam (Afianto, 2013:130).

Menurut pandangan mazhab Maliki, murtadnya salah-satu pasangan dapat menyebabkan putusnya ikatan perkawinan yang telah dilangsungkan. Namun demikian, apabila salah seorang suami atau istri murtad, terdapat 
sedikit perbedaan pendapat dalam Mazhab Maliki mengenai status perkawinan mereka. Perbedaan pendapat tersebut antara lain sebagaimana uraian di bawah ini (Afianto, 2013:131):

a. Bila yang murtad adalah pihak istri, ikatan perkawinan mereka putus seketika. Putusnya perkawinan itu dengan jalan talak ba'in. Ini adalah pendapat Ibn al-Qasim, Ashhab, dan alQayrwani.

b. Namun Ashhab memberikan pendapat tambahan, bahwa bila wanita itu kembali masuk agama Islam, ia tetap menjadi istri bagi suaminya.

c. Bila yang murtad adalah pihak suami, ikatan perkawinan mereka putus seketika.

Menurut pendapat Mazhab Syafi'i, perbuatan serta akibat murtad dalam kaitannya dengan ikatan perkawinan dibedakan menjadi 2 (dua) macam, yaitu perbuatan murtad dalam perkawinan yang dilakukan sebelum $d u k h u l$, dan perbuatan murtad dalam perkawinan yang dilakukan setelah dukhul. Hukum murtad terhadap status pernikahan ialah bahwa jika perbuatan murtad yang dilakukan sebelum dukhul, maka status pernikahannya menjadi putus setelah murtadnya salah-satu pasangan. Perceraian tersebut telah dinyatakan putus setelah salah-satu pasangan melakukan perbuatan murtad karena dalam pandangan Madzhab Syafi' i murtad dikategorikan sebagai perbuatan yang menyebabkan putusnya suatu ikatan suci perkawinan (Natsir, 2016: 277).

Namun demikian, bila perbuatan murtad itu terjadi setelah dilakukannya dukhul, status perceraian perkawinan itu ditangguhkan hingga berakhirnya masa iddah. Setelah masa iddah berakhir, status perceraiannya telah jatuh dan seketika itu pula ikatan perkawinan antar pasangan itu telah putus. Meski demikian, di tengah berlangsungnya masa iddah kemudian si pihak yang murtad kembali masuk Islam, status perkawinan itu tetap utuh dan dapat dilangsungkan sebagaimana sedia kala. Sedangkan bila setelah selesainya masa iddah berakhir, dan pihak yang murtad belum juga kembali meyakini Islam sebagai agama yang benar dengan konsekuensi pemelukan dirinya terhadap Islam, maka perkawinan itu telah putus bersamaan dengan berakhirnya masa iddah yang telah dilangsungkan.

Menurut pandangan Mazhab Hambali, status perkawinannya menjadi putus diakibatkan oleh kemurtadan salah-satu pasangan di atas. Meski begitu dalam Madzhab ini juga membedakan antara murtad yang dilakukan sebelum dukhul dan murtad yang dilakukan setelah dukhul. Murtadnya salah-satu pasangan sebelum terjadinya dukhul dalam pandangan Madzhab Hambali akan berakibat pada putusnya hubungan perkawinan seketika setelah perbuatan murtad itu dilakukan. Bahkan dalam pandangan ini, hubungan yang dilakukan oleh pasangan itu dapat dikategorikan sebagai perbuatan zina karena hubungan perkawinan antara keduanya telah putus.

Terkait dengan murtad yang dilakukan setelah dukhul, dalam madzhab ini terjadi selisih pendapat terkait proses putusnya suatu perkawinan. Pendapat pertama menyatakan bahwa status pernikahannya furqah dan harus disegerakan. Pendapat ini didasarkan atas fasakh-nya ikatan perkawinan itu sama-saja antara sebelum dan setelah dukhul, sebagaimana kasus sepersusuan. Sedangkan pendapat lainnya menyatakan bahwa furqah ditangguhkan hingga berakhirnya masa iddah. Bila pihak yang murtad kembali masuk Islam sebelum berakhirnya masa iddah, maka hubungan perkawinan yang telah dilakukan tetap utuh sebagaimana mestinya. Namun bila belum juga kembali masuk Islam hingga berakhirnya masa iddah, istri seketika ba'in dimulai sejak terjadinya perbuatan murtad, karena ia merupakan lafadh yang dengannya terjadi furqah. Bila ia ada setelah dukhul, ia boleh menunggu hingga berakhirnya masa iddah, sama dengan talak raj' $i$ atau perbedaan agama setelah dukhul, sehingga tidak diharuskan fasakh seketika, seperti Islamnya seorang habiyah yang dalam perkawinan dengan seorang harbi (Afianto, 2013:133-135).

Berdasarkan ketentuan di atas dapat diketahui bahwa dalam ketentuan hukum Islam, murtadnya salah-satu pasangan dalam pernikahan dapat menjadi penyebab atau alasan atas putusnya suatu ikatan perkawinan yang telah dilangsungkan sebelumnya (Husaini, tanpa tahun). Ketentuan yang demikian kemudian diformalkan dalam aturan hukum positif Indonesia sebagaimana termaktub dalam ketentuan pasal 116 huruf (h) Kompilasi Hukum Islam. Dengan demikian, seorang yang melakukan perbuatan murtad maka status perkawinannya menjadi putus (Ali, 2006:59).

Namun demikian, putusnya perkawinan akibat murtad dalam ketentuan Pasal 116 huruf (h) Kompilasi Hukum Islam tidak secara langsung memberikan aturan putusnya suatu perkawinan, 
akan tetapi kemurtadan tersebut harus disertai oleh keadaan tidak rukun dalam keluarga. Dengan dasar hukum ini, murtad tidak langsung menjadi alasan putusnya perkawinan, karena Kompilasi Hukum Islam memberikan aturan bahwa putusnya perkawinan dapat dilakukan dengan alasan murtad yang menyebabkan ketidak-rukunan dalam keluarga.

\section{Kewenangan Peradilan Agama Dalam Memutus Perkara Perceraian Akibat Murtad}

Jika merujuk pada asas persoanalisasi yang melekat pada pengadilan agama, maka lembaga peradilan ini hanya berwenang menangani perkaraperkara seputar pernikahan, perceraian, zakat, hibah, infaq, shadaqoh, wakaf, dan ekonomi syari'ah, bagi orang-orang yang beragama Islam, sebagaimana ketentuan Pasal 49 Undang-Undang Nomor 3 Tahun 2006 Tentang Peradilan Agama. Berdasarkan ketentuan ini, pihak-pihak yang bisa berperkara di pengadilan agama hanyalah orangorang yang beragama Islam, sementara orangorang yang tidak beragama Islam semestinya tidak boleh berperkara di pengadilan agama.

Pada kenyataannya banyak ditemui perkaraperkara yang ternyata memberikan peluang bagi orang yang tidak beragama Islam untuk beracara di pengadilan agama. Salah satunya ialah pada kasus perceraian yang diakibatkan oleh murtadnya salah-satu pasangan. Murtad berarti bahwa orang tersebut telah keluar dari meyakini agama Islam, atau dengan kata lain telah memilih dan memeluk agama lain di luar Islam.

Salah-satu fakta yang dimaksud ialah putusan cerai yang dikeluarkan oleh Peradilan Agama Pekanbaru dengan putusan nomor 354/Pdt.G/ 2013/PA.PBR. Dalam kasus ini, suami dari pasangan ini merupakan orang yang baru masuk Islam (muallaf) sebagai syarat diberlangsungkan suatu prosesi pernikahan bagi wanita muslimah. Pasangan inipun dapat melangsungkan pernikahan pada tanggal 14 Juli 2006 yang berlangsung di Kantor Urusan Agama (KUA) Kecamatan Rumbai Pesisir, Kota Pekanbaru sebagaimana bukti Buku Kutipan Akta Nikah No. 389/44/VII/ 2006 tertanggal 20 Juli 2006. Pasangan suami-istri ini dapat melangsungkan kehidupan bersamanya selama kurang lebih 5 (lima) dan dikaruniai dua orang putra-puteri (Putusan Peradilan Agama Pekanbaru Nomor: 354/Pdt.G/2013/PA.PBR).

Pada awalnya, kehidupan rumah tangga yang dijalani oleh pasangan suami-istri tersebut berlangsung harmonis dan penuh dengan nuansa kebersamaan, sekalipun dalam waktu-waktu tertentu sempat terjadi perselisihan-perselisihan kecil yang dapat terselesaikan secara cepat. Namun semenjak suami menyatakan diri keluar dari agama Islam dan kembali memeluk agama Kristen Protestan pada awal Desember tahun 2012, kehidupan keluarga kecil ini terus dilanda berbagai macam gejolak dan permasalahan yang tidak lagi dapat diselesaiakan secara damai. Artinya, pertikaian yang terjadi antara kedua pasangan tersebut tidak dapat lagi mempertahankan ikatan perkawinan yang telah dibina selama 5 tahun (Putusan Peradilan Agama Pekanbaru Nomor: 354/ Pdt.G/2013/PA.PBR).

Pada akhirnya si istri dikemudian hari melayangkan gugatan cerai kepada Pengadian Agama Pekanbaru pada tanggal 7 Maret 2013. Alasan pokok dilayangkannya gugatan cerai oleh istri tersebut ialah status murtad yang melekat kepada suami yang berakibat pada pertikaian dalam keluarga yang tidak dapat diselesaikan dan dipertahankan lagi keutuhan keluarganya. Alasan yang demikian telah sesuai dengan ketentuan alasan boleh diajukannya gugatan perceraian ke peradilan agama sebagaimana termaktub dalam ketentuan Pasal 116 huruf h Kompilasi Hukum Islam yang membolehkan alasan murtad sehingga menyebabkan perselisihan, pertikaian, dan pertentangan dalam kehidupan rumah-tangga sebagai alasan diajukannya gugatan cerai ke Peradilan Agama.

Pada akhirnya gugatan yang diajukan oleh Penggugat dalam kasus ini dikabulkan oleh Majelis Hakim Pengadilan Agama Pekanbaru. Alasan hukum yang dijadikan landasan oleh Majelis Hakim ialah: (Putusan Peradilan Agama Pekanbaru Nomor: 354/Pdt.G/2013/PA.PBR).

a. Ketentuan Pasal 2 ayat (1) Undang-Undang Nomor 1 Tahun 1974 tentang Perkawinan, mengamantkan bahwa ikatan perkawinan hanya bisa dilangsungkan menurut agama masing-masing, dalam konteks ini adalah Islam, sedangkan Islam mengharamkan hubungan perkawinan antara orang yang tidak beragama Islam. Keluarnya salah-satu pasangan dari agama Islam merupakan suatu yang bertentangan dengan ketentuan di atas sehingga alasan perceraian yang diajukan dapat diterima dan diputuskan.

b. Ketentuan Pasal 116 huruf h Kompilasi Hukum Islam yang menegaskan bahwa perilaku 
murtad yang menyebabkan terjadinya ketidakrukunan hubungan antara suami istri merupakan alasan yang diperbolehkan oleh aturan ini untuk diajukannya suatu gugatan cerai pada peradilan agama. Pada perkara ini, semenjak murtadnya suami, kondisi kehidupan rumah tangga berjalan tidak rukun, bahkan suami telah meninggalkan rumah jauh sebelum gugatan tersebut diajukan ke peradilan agama. Dengan kondisi yang demikian, Majelis Hakim menilai bahwa alasan yang diajukan dalam gugatan cerai memenuhi persyaratan untuk kemudian dapat diterima oleh Majelis Hakim pada Peradilan Agama Pekanbaru.

Penerapan asas personalitas keislaman dalam Peradilan Agama didasarkan pada Pasal 1 angka 1 jo Pasal 49 ayat (1) jo penjelasan umum angka 2 alinea 2 Undang-undang nomor 7 tahun 1989 tentang Peradilan Agama, yang intinya bahwa yang berhak berperkara di Peradilan Agama adalah mereka yang beragama Islam dalam perkara perdata tertentu. Selain itu juga didasarkan pada yurisprudensi Putusan Mahkamah Agung Republik Indonesia Nomor 726 K/Sip/1976 yang menyatakan bahwa penyelesaian sengketa perkawinan (perceraian) ditentukan berdasarkan hubungan hukum pada saat perkawinan bukan agama yang dianut para pihak pada saat sengketa terjadi. Sehingga penerapan asas personalitas keislaman didasarkan pada hubungan hukum yang melandasi terjadinya sengketa.

Menurut Abdul Rahman Ghazali, apabila perkawinan tersebut dilangsungkan berdasarkan hukum Islam dan dilakukan di Kantor Urusan Agama, maka segala permasalahan yang terjadi setelah perkawinan diselesaikan sesuai ketentuan hukum Islam dan hal ini menjadi kewenangan absolut Peradilan Agama (Ghazali, 2003: 45-47). Ghazali menambahkan bahwa penjelasan di atas itulah yang dimaksud dengan Asas Personalitas Keislaman sebagaimana dimaksud pada ketentuan Pasal 2 dan 49 ayat (1) UU No. 7 Tahun 1989 yang telah dirubah dengan Undang-Undang Nomor 3 Tahun 2006, dan perubahan kedua Undang-Undang Nomor 50 Tahun 2009, yang berbunyi: "Asas personal keIslaman adalah asas yang menyatakan bahwa yang tunduk dan yang dapat ditundukan pada lingkungan Peradilan Agama adalah mereka yang beragama Islam, rakyat yang tidak beragama Islam atau non-Islam tidak dapat dipaksa untuk tunduk pada Peradilan Agama" (Ghazali, 2003: 46).
Keterangan yang demikian dikarenakan peradilan agama yang diposisikan sebagai suatu Peradilan yang diperuntukkan bagi umat Islam dalam memecahkan suatu persoalan atau masalah. Hal ini pun berlaku jika terjadi perkawinan secara Islam (perkawinan dilangsungkan di KUA), namun dalam perjalanan perkawinan tersebut salah seorang, baik suami atau istri menjadi murtad, maka kewenangan untuk menangani permasalahan tersebut berdasarkan yurisprudensi Putusan Mahkamah Agung R.I Nomor 726 K/Sip/ 1976 tanggal 15 Februari 1976 itulah yang menjadi dasar kewenangan Peradilan Agama (berdasarkan penundukan hukum pertama kali melangsungkan perkawinan). Sehingga penerapan asas personal keislaman didasarkan pada hubungan hukum yang melandasi terjadinya sengketa bukan agama yang dianut para pihak pada saat sengketa terjadi (Ghazali, 2003: 47).

Ketentuan yang lebih mengikat tentang kewenangan Peradilan Agama untuk bertugas dan menyelesaikan perkara cerai murtad yaitu berdasarkan hasil Rapat Kerja Nasional Mahkamah Agung Republik Indonesia pada tahun 2005 bagian C Bidang Badilag angka 3 huruf (a), yang menyatakan bahwa "Peradilan Agama berwenang mengadili seseorang (pihak) yang sudah murtad, karena yang menjadi ukuran untuk menentukan berwenang atau tidaknya Peradilan Agama adalah hukum yang berlaku pada waktu pernikahan dilangsungkan dan bukan berdasarkan agama yang dianut pada saat sengketa terjadi.

Dengan dasar yang demikian, Peradilan Agama berwenang dalam mengadili dan memutus perkara perceraian yang diakibatkan oleh murtad. Alasannya ialah bahwa kewenangan tersebut diberikan oleh peraturan perundang-undangan yang dijadikan dasar bagi suatu lembaga atau organisasi kenegaraan untuk melakukan aktifitas kelembagaannya. Dasar hukum berupa Yurisprudensi Putusan Mahkamah Agung Republik Indonesia Nomor 726 K/Sip/ 1976 serta Rapat Kerja Nasional Mahkamah Agung Republik Indonesia pada tahun 2005 bagian C Bidang Badilag angka 3 huruf (a), merupakan dasar hukum yang memberikan kewenangan bagi Peradilan Agama dalam memutus dan menyelesaikan perkara perceraian yang diakibatkan oleh salah-satu pasangan murtad (Mahkamah Agung Republik Indonesia, 2005: 3-4).

Di samping kewenangan yang diberikan oleh peraturan perundang-undangan tersebut, dasar kewenangan Peradilan Agama dalam memutus 
dan menyelesaikan perkara perceraian yang diakibatkan oleh murtadnya salah-satu pasangan, kewenangan tersebut juga didapatkan oleh tradisi dalam dunia peradilan yang telah lama dipraktekkan oleh peradilan agama untuk memutus dan menyelesaikan perkara perceraian akibat salah-satu pasangan murtad. Perkara demikian sebenarnya telah lama dipraktekkan oleh peradilan agama di Indonesia. Pada kasus ini, kebiasaan hukum yang dipraktekkan Peradilan Agama tersebut dapat dijadikan sebagai sumber kewenangan yang memberikan legitimasi bagi Peradilan Agama dalam memutus dan menyelesaikan perkara perceraian akibat murtad (Afdol, 2006:46).

Keilmuan ilmu hukum telah menggariskan bahwa kebiasaan hukum merupakan salah-satu sumber hukum yang dapat dijadikan landasan untuk melakukan suatu kebijakan tertentu ataupun suatu tindakan kenegaraan tertentu. Bahkan pada suatu tertentu, hukum kebiasaan dapat disejajarkan kekuatan mengikatnya dengan peraturan perundang-undangan tertulis, hal ini dikarenakan hukum kebiasaan merupakan salah-satu sumber hukum yang telah disepakati oleh berbagai ilmuan Ilmu Hukum (pakar/sarjana hukum) (Kansil, 2003:48). Dengan berpegang pada kebiasaan hukum ini, peradilan agama memiliki kewenangan dalam memutus dan menyelesaikan perkara perceraian yang diakibatkan oleh murtadnya salah-satu pasangan dalam suatu ikatan perkawinan.

Berpijak pada penjelasan di atas, dapat diketahui bahwa Peradilan Agama memiliki kewenangan dalam memutus dan menyelesaikan perkara perceraian akibat murtad. Dasar kewenangan tersebut diperoleh dari Yurisprudensi Putusan MA No. 726 K/Sip/ 1976 dan hasil Rapat Kerja Nasional MK RI tahun 2005 bagian C Bidang Badilag angka 3 huruf (a) yang menyatakan bahwa peradilan agama berwenang memutus dan menyelesaikan perkara perceraian akibat murtad. Terkait dengan status agama di luar Islam yang dipeluk bukan merupakan suatu

\section{DAFTAR RUJUKAN}

Afdol, 2006. Kewenangan Peradilan Agama Berdasarkan UU No. 3 Tahun 2006 dan Legislasi Hukum Islam di Indonesia, Surabaya: Airlangga University Press. pengahalang bagi Peradilan Agama untuk menggelar perkara tersebut, karena status agama yang dilihat ialah pada saat pernikahan itu dilangsunngkan, bukan pada saat perkara disidangkan. Dengan demikian, jawaban atas persoalan berwenang-tidaknya peradilan agama dalam memutus perkara perceraian akibat murtad ialah bahwa peradilan agama memiliki kewenangan dalam memutus dan menyelesaikan perkara tersebut.

\section{SIMPULAN}

Berdasarkan segala yang terurai pada pembahasan di atas, dapat disimpulkan bahwa murtad dapat dijadikan suatu alasan putusnya ikatan perkawinan. Pendapat ini didasarkan pendapat mayoritas imam mazhab yang memberikan hukum talak terhadap pelaku murtad. Sementara dalam KHI, sebagaimana diatur dalam Pasal 116 huruf h KHI menyatakan bahwa murtad dapat dijadikan alasan putusnya perkawinan, tapi murtad tersebut harus disertai oleh perselisihan dan pertengkaran.

Pengadilan agama dinyatakan berwenang memutus perkara perceraian akibat murtad, ini didasarkan oleh ketentuan a) Yurisprudensi Putusan Mahkamah Agung Republik Indonesia Nomor 726 K/Sip/ 1976 dan hasil Rapat Kerja Nasional Mahkamah Agung Republik Indonesia pada tahun 2005 bagian C Bidang Badilag angka 3 huruf (a), dasar hukum di atas menyatakan bahwa pengadilan agama berwenang dalam memutus perkara perceraian akibat murtad, karena status hukum yang dilihat ialah saat dilangsungkannnya perkawinan.

Rekomendasi dalam tulisan ini ialah bahwa pengaturan kedepan tentang kewenangan pengadilan agama yang berwenang memutus perkara perceraian akibat murtad harus diatur secara terperinci dalam produk hukum setingkat undang-undang. Pengaturan tersebut bisa diatur dalam UU Peradilan Agama dan/atau UU Perkawinan.

Afianto, Ahda Bina. 2013. Status Perkawinan Jika Suami atau istri Murtad dalam Kompilasi Hukum Islam, Jurnal Humanity, Universitas Muhammadiyah Malang, Vol. 9 No. 1 Th.2013. 
Amiruddin. Zainal Asikin, 2004. Pengantar Penelitian Hukum, Jakarta, Rajawali Pers.

Basuki, A. Singgih. 2013. Kebebasan Beragama Dalam Masyarakat; Studi Tentang Pindah Agama dan Konsekuensinya Menurut Pemikir Muslim Kontemporer, Jurnal Religi Fakultas Ushuluddin Universitas Islam Negeri Sunan Kalijaga Vol. IX No. 1.

Ghazali, Abd. Rahman. 2003. Fiqh Munakahat, Jakarta: Kencana Prenada Media.

Hasan, Sofyan. 2003. Hukum Islam: Bekal Pengantar Ilmu Hukum dan Tata Hukum Islam di Indonesia, Jakarta: Literata Lintas Media.

Husaini. Tanpa tahun. Putusnya Perkawinan Karena Murtad; Telaah Kritis Terhadap Pasal 116 huruf h Kompilasi Hukum Islam, Makalah.

Kansil, C.S.T. 2003. Pengantar Ilmu Hukum dan Tata Hukum Indonesia, Jakarta: Balai Pustaka.

Mahkamah Agung Republik Indonesia, 2005. Jawaban Atas Pertanyaan yang Diajukan PTA se Indonesia Dalam Rakernas MARI Tahun 2005, Denpasar $18 \mathrm{~s} / \mathrm{d} 22$ September 2005.

Marpaung, Happy. 1983. Masalah Perceraian. Bandung:Tonis.

Moqshit, Abd. Tafsir Atas Hukum Murtad Dalam Islam, 2014. Jurnal Ahkam, Vol XIII No. 2, Jakarta: Fakultas Syariah dan Hukum Universitas Islam Negeri Syarif Hidayatullah Jakarta.
Nafis, M. Cholil. 2015. Fikih Kebangsaan; Studi Historis dan Konseptual Perbandingan Kehidupan Beragama dalam Negara Bangsa, Jakarta: Mitra Abadi Press.

Natsir, Abdul. 2016. Studi Tentang Fasakhnya Perkawinan Karena Murtad Menurut Syafi'iyahdan Kompilasi Hukum Islamdi Indonesia, Jurnal Sumbula, Fakultas Syari'ah Universitas Darul Ulum Jombang, Vol. 1, No. 2, 2016.

Republik Indonesia. 2006. Undang-Undang Nomor 3 Tahun 2006 tentang Perubahan atas Undang-Undang Nomor 7 Tahun 1989 Tentang Peradilan Agama.

Republik Indonesia. 1989. Undang-Undang Nomor 7 Tahun 1989 tentang Peradilan Agama.

Republik Indonesia. 1974. Undang-Undang Nomor 1 Tahun 1974 tentang Perkawinan.

Subekti, Trusto. 2010. Sahnya Perkawinan Menurut Undang-Undang Nomor 1 Tahun 1974 Tentang Perkawinan Ditinjau Dari Hukum Perjanjian, Jurnal Dinamika Hukum. Vol. 10 No. 3 September 2010.

Syaifuddin, Muhammad. Sri Turatmiyah, Annalisa Yahanan. 2013. Hukum Perceraian, Jakarta: Sinar Grafika.

Zuhriah, Erfaniah. 2014. Peradilan Agama Indonesia; Sejarah Konsep dan Praktik di Peradilan. Agama, Malang: Setara Press. 